\title{
Optimization of Apple Pollen Culture and Its Maintenance of Pollen Germination Capacity
}

\author{
Sh. Mehri ${ }^{1}$, S. Piri ${ }^{2}$ and A. Imani ${ }^{3}$
}

\begin{abstract}
Temperate fruits including pome fruits, especially apple are important fruit crops which mostly for fruit set needs the pollination of flowers and followed by pistil fertilization. Therefore, to achieve this act, pollen viability and its germination capability is essential. For that reason, test of pollen viability and understand its quality is important. By the same token, test to optimize the pollen medium of apple and determination best medium for it with 16 types of culture medium containing different concentrations of boric acid (0 and 100mg/1), calcium nitrate(0and300mg/l‘) , soleplate magnesium $(0$ and $200 \mathrm{mg} / \mathrm{l})$, potassium nitrate $(0$ and 100 $\mathrm{mg} / \mathrm{l})$,sucrose $(15 \%)$ and agar $(1 \%)$ in the In-vitro using random complete design with three replications. The results showed that maximum germination was in combination medium $\mathrm{B}_{2} \mathrm{M}_{1} \mathrm{~K}_{1} \mathrm{C}_{2} \mathrm{~S}$ $(100 \mathrm{mg} / \mathrm{l}$ boric acid, $0.0 \mathrm{mg} / \mathrm{l}$ soleplate magnesium, $0.0 \mathrm{mg} / \mathrm{l}$ potassium nitrate, $300 \mathrm{mg} / \mathrm{l}$ calcium nitrate , $15 \%$ sucrose and $1 \%$ agar) with $100 \%$, and lowest germination medium in combination $\mathrm{B}_{1} \mathrm{M}_{2} \mathrm{~K}_{2} \mathrm{C}_{1} \mathrm{~S} \quad(0.0 \mathrm{mg} / \mathrm{l}$ boric acid, $100 \mathrm{mg} / \mathrm{l}$ potassium nitrate, 200mg/l soleplate magnesium, $0 \mathrm{mg} / \mathrm{l}$ calcium nitrate , $13 \%$ sucrose and $1 \%$ agar with $13.40 \%$ occurred. The viability of pollen of 4 apple cultivars, three months after maintenance at 3temperatures $\left(+4^{\circ} \mathrm{C},-20^{\circ} \mathrm{C}\right.$ and $\left.-80^{\circ} \mathrm{C}\right)$ showed that maximum germination was in Primgold Pollen stored at $-80^{\circ} \mathrm{C}$ with $94.66 \%$ and the lowest germination (36.66\%) in Nothern Spy pollen stored at $+4^{\circ} \mathrm{C}$.germination in early was high but germination further decreased.
\end{abstract}

Keywords - In-vitro, pollen germination, Apple.

\section{INTRODUCTION}

$\mathrm{T}$ EMPERATE fruits including pome fruits, especially apple is important fruit crops which mostly for fruit set needs the pollination of flowers and followed by pistil fertilization. Therefore, pollen viability and its germination capability are essential. The biological review indicated that the pollen grains in the especial environment have the good growth and germination. On the other hand, the basic components of medium pollen contains calcium, boric acid, magnesium, potassium and sucrose are. In general, compounds in the pollen medium at different concentrations are found. In addition, these elements, $\mathrm{pH}$ and temperature growth medium are two important factors that germination and growth are affected (Boavida and McCormick, 2007; Chebli and Geitmann, 2007). Among the elements of the

\footnotetext{
${ }^{1}$ Department of Agronomy and Plant Breeding, Pars Abad Moghan Branch, Islamic Azad University, Pars Abad Moghan, Iran

${ }^{2,3}$ Department of Horticulture , Abhar Branch, Islamic Azad University, Abhar, Iran.
}

primary role B in the development of pollen has been cleared so that $\mathrm{B}$ as a the proposed structure prerequisite in the development of cell walls of pollen participate (Matoh et al., 1996; Fleischer et al., 1998).

Role of calcium in pollen tube growth in recent years also has been reported(Malho et al., 1994; Malho and Trewevas, 1996; Malho et al., 2000). Preserving viability of pollen in order to eliminate the problem in time and place of artificial pollination, more attention has been (Khosh-khui et al., 1976).

viability pollen is determinate by deferent methods including culture on a drop through the sucrose solution (2.5 to 20\%) (Amma and Kulkarni, 1979), staining with Acitocarman(Ganeshan and Alexander. 1991; Alexander, 1996). Stanley and Linskens(1974)concentration of $10 \%$ sucrose, $5 \%$ agar suggest $100 \mathrm{ppm}$ Boric acid at $20^{\circ} \mathrm{C}$ for germination and pollen tube growth as effective medium were reported. It was fond that pollen germination in culture media containing sucrose, Boric acid and calcium nitrate, calcium plays an important role (Brewbacker and Kwack, 1963),despite the fact that the different effects of various culture media on pollen germination of some cultivars and species than has been reported (Mehan and Malik, 1975, Brewbacker and Kwack, 1963, Khan and. Perveen, 2006a). In the same way, investigation for ptimization of apple pollen culture and the viability pollen of 4 apple cultivars, three months after maintenance at 3temperatures at different times were carried out.

\section{MATERIALS AND METHODS}

Branches with unopened flowers were pruned from trees of 4 apple cultivars (M.9, Nothern Spy,Primgold and Golab) growing in commercial orchards. Pollen was collected in large quantity from the cuttings, after $24 \mathrm{~h}$, freshly opened blossoms. To optimize the pollen medium of apple and determination best medium for apples, Pollen culture media were prepared with 16 types of culture medium containing different concentrations of boric acid (0 and 100mg/1), calcium nitrate $(0$ and $300 \mathrm{mg} / 1$ ، $)$, soleplate magnesium $(0$ and $200 \mathrm{mg} / \mathrm{l})$, potassium nitrate $(0$ and $100 \mathrm{mg} / \mathrm{l})$ sucrose $(15$ $\%)$ and agar (1\%).After fresh pollen culture, Pollen tube equal to at least twice the diameter of pollen grains were counted as germinated, burst pollen were not counted as germinated. The viability of pollen of 4 apple cultivars, three months after maintenance at 3temperatures $\left(+4^{\circ} \mathrm{C},-20^{\circ} \mathrm{C}\right.$ and 
$-80^{\circ} \mathrm{C}$ ) was assessed in optimized pollen medium in terms of germination percentage. Light microscopy was carried out under Nikon type-2 microscope.

\section{RESULTS AND DISCUSSION}

If you are using Word, use either the Microsoft Equation Editor or the MathType add-on (http://www.mathtype.com) for equations in your paper (Insert | Object | Create New | Microsoft Equation or MathType Equation). "Float over text" should not be selected.

\section{UNITS}

The results from 16 types of medium composition on pollen germination in apple Fig. 1 and 2 are presented.

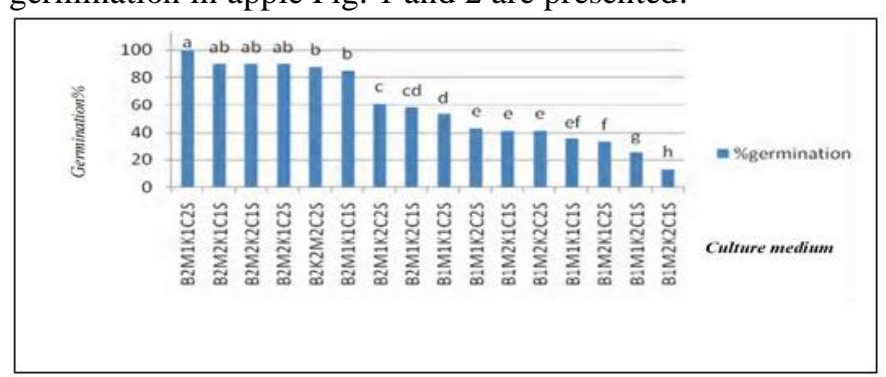

Fig. 1: Effect of different culture media on pollen germination of apple Nothern Spy

MKBCS: soleplate magnesium $=\mathrm{m}$ ، potassium nitrate $=\mathrm{k}$ ، boric acid $=\mathrm{b}$ ، calcium nitrate $=\mathrm{c}$ sucrose $=\mathrm{s}$

$\mathrm{M} 1=0 \mathrm{mg} / \mathrm{l} \cdot \mathrm{K} 1=0 \mathrm{mg} / \mathrm{l}$ ، $\mathrm{C} 1=\mathrm{Omg} / \mathrm{l}$ ‘B1=Omg/1 $\mathrm{M} 2=200 \mathrm{mg} / \mathrm{l}$ ، $\mathrm{K} 2=100 \mathrm{mg} / \mathrm{l} \cdot \mathrm{C} 2=300 \mathrm{mg} / \mathrm{l}$ ، B2=100mg/l $\mathrm{S}=15 \%$

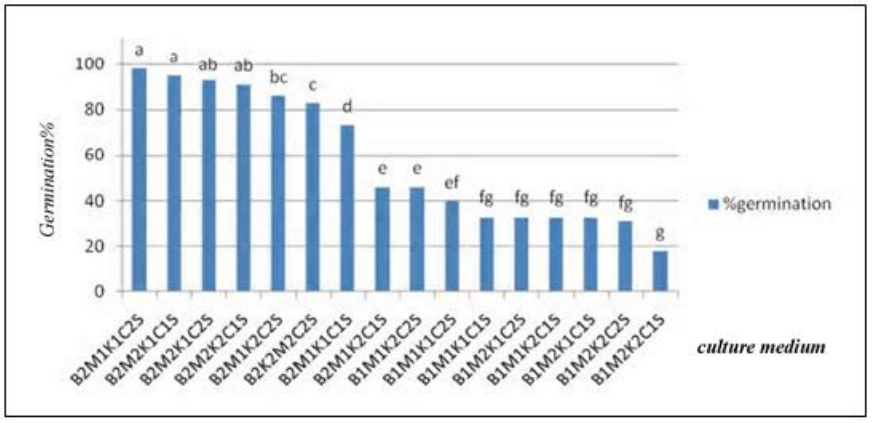

Fig. 2: Effect of different culture media on pollen germination of apple M.9

The results from apple pollen germination in 16 types of medium composition in Fig.1and Fig.2 showed that maximum germination(for example Nothern Spy ) was in combination medium $\mathrm{B}_{2} \mathrm{M}_{1} \mathrm{~K}_{1} \mathrm{C}_{2} \mathrm{~S}(100 \mathrm{mg} / \mathrm{l}$ boric acid, $0.0 \mathrm{mg} / 1$ soleplate magnesium, $0.0 \mathrm{mg} / 1$ potassium nitrate, 300 $\mathrm{mg} / \mathrm{l}$ calcium nitrate, $15 \%$ sucrose and $1 \%$ agar) with $100 \%$ , and lowest germination medium in combination $\mathrm{B}_{1} \mathrm{M}_{2} \mathrm{~K}_{2} \mathrm{C}_{1} \mathrm{~S}$ $(0.0 \mathrm{mg} / \mathrm{l}$ boric acid, $100 \mathrm{mg} / \mathrm{l}$ potassium nitrate, $200 \mathrm{mg} / \mathrm{l}$ soleplate magnesium, $0 \mathrm{mg} / \mathrm{l}$ calcium nitrate , $15 \%$ sucrose and $1 \%$ agar with $13.30 \%$ occurred. Significant difference between cultivars in the ability for germination and pollen tube growth was not observed (Fig.1 and Fig.2). So we can say with certainty medium optimized for two varieties of M.9 and Northern Spy about the same and can be used to test viability of other varieties of apple, although the ability to compare germination between cultivars of different species have been reported deferent (Picchioni and Weinbaum, 1995).

The pollen was determined both varieties of apple Northern Spy and M.9 lowest germination in most media without boric acid compared to media containing boric acid found (Table 2). Because such elements are reportedly on the medium to promote pollen tube growth is essential and can form complex sugar - for you to participate and absorption, transport and metabolism of sugars in the pollen and the increase in pectin synthesis may contribute to the pollen tube cell wall formation in developing active is important. (Chene et al., 1998).

On the other hand the results of this study it was shown that germination in culture media containing Boric acid $100 \mathrm{mg} / \mathrm{l}$ compared with $0 \mathrm{mg} / \mathrm{l}$ and calcium nitrate 300 compared to low concentration of calcium nitrate was more effective .According to the report of Brewbacker and Kwack (1963) as well as the presence of calcium in the pollen culture medium with appropriate concentration if applied to an important role in pollen germination plays, but if not used with optimal concentration of inhibitory effects of different and sometimes to cause toxicity in the medium that occur in this case study pollen germination of some cultivars and species have been reported (Mehan and Malik, 1975, Brewbacker and Kwack, 1963, Khan and Perveen, 2006b).

The viability of pollen of 4 Apple cultivars, three months after maintenance at 3temperatures $\left(+4^{\circ} \mathrm{C},-20^{\circ} \mathrm{C}\right.$ and $\left.-80^{\circ} \mathrm{C}\right)$ showed that maximum germination was in Primgold Pollen stored at $-80^{\circ} \mathrm{C}$ with $94.66 \%$ and the lowest germination $(36.66 \%)$ in Nothern Spy pollen stored at $+4^{\circ} \mathrm{C}$ (Table 1$)$.

These findings agree with the results of stored pollen germination of strawberry (Aslantus and Pirlak, 2002) .It be hoped the results of this research is used to pollination management and hybridization programs of apple.

TABLE I: MEAN COMPARISON OF POLLEN GERMINATION OF 4 APPLE CULTIVARS, 3 MONTHS AFTER MAINTENANCE AT TEMPERATURES

\begin{tabular}{|c|c|c|}
\hline Apple cultivar & $\begin{array}{c}\text { maintenance at } \\
\text { temperature }\left({ }^{\circ} \mathrm{C}\right)\end{array}$ & $\begin{array}{c}\text { pollen } \\
\text { germination(\%) }\end{array}$ \\
\hline Primgold & -80 & $94.66 \mathrm{a}$ \\
\hline Primgold & -20 & $76.66^{\mathrm{b}}$ \\
\hline Golab & -80 & $75.00^{\mathrm{b}}$ \\
\hline M9 & -80 & $68.33^{\mathrm{bc}}$ \\
\hline Primgold & 4 & $66.66^{\mathrm{cb}}$ \\
\hline Golab & -20 & $66.66^{\mathrm{bc}}$ \\
\hline M9 & -20 & $66.66^{\mathrm{bc}}$ \\
\hline Golab & 4 & $63.33^{\mathrm{c}}$ \\
\hline M9 & 4 & $63.33^{\mathrm{c}}$ \\
\hline Nothern Spy & -80 & $53.33^{\mathrm{d}}$ \\
\hline Nothern Spy & -20 & $46.66 \mathrm{e}$ \\
\hline Nothern Spy & 4 & $36.67 \mathrm{f}$ \\
\hline
\end{tabular}

\section{REFERENCES}

[1] Alexander, M.P. 1996. Different staining of aborted and non-aborted pollen. Stain Technology, 44: 117-122. 
[2] Aslantus, R.; Pirlak, L. 2002. Storage of strawberry pollen. IV International Symposium on strawberry pollen. (Eds.): M. Hietaranta, M.L Palonen \& P. Parikka. Acta Hortculture, 2:567.

[3] Amma, M.S.P. ; Kulkarni, A.R. 1979. Pollen storage in organic solvents. J. Palyn., 15:100-104.

[4] Boavida, L.C.; McCormick, S.M. 2007. Temperature as a determinant factor for increased and reproducible in vitro pollen germination in Arabidopsis thaliana. Plant Journal. 52(3):570-582. http://dx.doi.org/10.1111/j.1365-313X.2007.03248.x

[5] Brewbacker, J.L ; Kwack,B.H. 1963. The essential role of calcium ion in pollen tube growth .Amer. J. Bot., 50: 859-865. http://dx.doi.org/10.2307/2439772

[6] Chebli Y, Geitmann A. 2007. Mechanical principles governing pollen tube growth. Functional Plant Science and Biotechnology 1: 232-245.

[7] Chene, Y.Z. ; Smagula, J.M. ; Litten, W. ; Dunham, S. 1998. Effect of boron and calcium foliar sprays on pollen germination and development, fruit set, seed development, and berry yield and quality in lowbush blueberry (Vaccinium angustifolium Ait.). J. Am. Soc. Hort. Sci. 123, 524-531.

[8] Fleischer, A. ; Titel, C. ; Ehwald, R. 1998. The boron requirement and cell wall properties of growing and stationary suspension-cultured Chenopodium album L. cells. Plant Physiol. 117, 1401-1410. http://dx.doi.org/10.1104/pp.117.4.1401

[9] Ganeshan, S.; Alexander M.P. 1991. Cryogenic preservation of Lemon (Citrus lemon Burm.) pollen. Garten-bauwissenschaft, 56: 228-230.

[10] Herrero, M.P. ; Johnson, R.R. 1980. High temperature stress and pollen viability of maize. Crop Sci. 20, 796-800. http://dx.doi.org/10.2135/cropsci1980.0011183X002000060030x

[11] Khan, S.A. ; Perveen A. 2006a. Germination capacity of stored pollen of Abelmoschus esculentus L. (Malvaceae) and their maintenance. Pak. J. Bot., 38(2): 233-236.

[12] Khan, S.A. ; Perveen, A. 2006b. Germination capacity of stored pollen of Solanum melongena L. (Solanaceae) and their maintenance. Pak. J. Bot., 38(4): 921-930.

[13] Khosh-Khui, M. ; Bassiri, A. ; Niknejad, M. 1976. Effects of temperature and humidity on pollen viability of six rose species. Canadian Journal of Plant Science 56: 5 17-523

[14] Matoh, T. ; Kawaguchi, S. ; Kobayashi, M. 1996. Ubiquity of a borate rhamnogalacturonan II complex in the cell walls of higher plants. Plant Cell Physiol. 37, 636-640. http://dx.doi.org/10.1093/oxfordjournals.pcp.a028992

[15] Malho, R. ; Read, N.D. ; Pais, M.S., Trewavas, A.J. 1994. Role of cytosolic-free calcium in the reorientation of pollen-tube growth. Plant J. 5, 331-341. http://dx.doi.org/10.1111/j.1365-313X.1994.00331.x

[16] Malho, R. ; Trewavas, A.J. 1996. Localized apical increases of cytosolic free calcium control pollen tube orientation. Plant Cell 8, 1935-1949. http://dx.doi.org/10.1105/tpc.8.11.1935 http://dx.doi.org/10.2307/3870403

[17] Malho, R. ; Camacho, L. ; Moutinho, A. 2000. Signalling pathways in pollen tube growth and reorientation. Ann. Bot. 85, 59-68. http://dx.doi.org/10.1093/oxfordjournals.aob.a010315 http://dx.doi.org/10.1006/anbo.1999.0991

[18] Mehan, M. ; Malik C.P. 1975. Studies on effect of different growth regulators on the elongation of pollen tube in Calotropis procera. J. Palyn., 11: 74-77.

[19] Nyomora, A.M.S. ; Brown, P.H. ; Pinney, K. ; Polito, V.S. 2000. Foliar application of boron to almond trees affects pollen quality. J. Am. Soc. Hort. Sci. 125, 265-270.

[20] Picchioni, G.A.; Weinbaum, S.A. 1995. Retention and kinetics of uptake and export of foliage-applied, labeled boron by apple, pear, prune, and sweet cherry leaves. J. Am. Soc. Hort. Sci. 120, 28-35.

[21] Stanley, R.G.; Linskens,H.F. 1974. Pollen biology, biochemistry and management. Springer,Verlag. Berlin, Heidelberg, New York. 